BISMA

(Bisnis dan Manajemen)
Volume 11, Nomor 1, Oktober 2018, 20-32

ISSN 2549-7790 (Online)

ISSN 1979-7192 (Print)

https://journal.unesa.ac.id/index.php/bisma/index

\title{
Persepsi Follower terhadap Pemasaran Restoran melalui Instagram di Surabaya
}

\author{
Regina Jokom ${ }^{1}$ \\ Universitas Kristen Petra ${ }^{1}$ \\ Email korespondesi: regina@ petra.ac.id
}

\begin{abstract}
Instagram is one of social media which is growing popular currently. Food photography trend causes restaurants use Instagram as one of their marketing tools. Therefore, this research aims to describe restaurant followers' perception toward the components of marketing communication in Instagram. The components of marketing communication used are context, communication, collaboration and connection. Furthermore, 791 questionnaires are collected through survey to the followers. The result shows followers perceived that the overall marketing communication is good. Among four components of marketing communication, context is perceived the best in terms of using understandable language and interesting picture or photo. On the other side, the collaboration needs to be improved. Therefore, restaurants need to enhance the content with more interesting and interactive posting instead of only give product or price information. In addition, restaurants should pay more attention to the follower's comments and questions by promptly answering and responding to it.
\end{abstract}

Keywords: instagram; marketing communication; restaurant; social media

Received: 26 Juni 2018

Reviewed: 20 Agustus 2018

Accepted: 19 September 2018

Published: 31 Oktober 2018

\section{PENDAHULUAN}

Perkembangan dunia digital pada jaman sekarang ini semakin terasa, tentunya dilihat dengan penggunaan media sosial yang semakin intensif. Survei We Are Social tahun 2015 menyatakan sebanyak 72 juta orang Indonesia telah aktif dan memiliki akun media sosial, bahkan menghabiskan waktu 29 menit lebih banyak untuk membuka media sosial daripada menonton televise (Digital Social Mobile, 2015). Fakta ini membuat media sosial menjadi bagian penting untuk berkomunikasi dan berbagi informasi dalam kehidupan sehari-hari, sehingga merubah perilaku konsumen (Kaplan 2010). Oleh karena itu, perusahaan perlu 
meresponi perubahan ini dengan mengembangkan fokus strategi pemasarannya ke arah media sosial. Salah satu media sosial yang sedang populer adalah Instagram, dimana Instagram menerapkan strategi berbasis visual yang mengakomodasi pengguna untuk membagikan foto dan video kepada pengikutnya (Lim \& Yazdanifard, 2014). Instagram dapat digunakan sebagai alat pemasaran yang memungkinkan perusahaan untuk berinteraksi dengan konsumennya dengan cara follow akun dan like pada gambar yang dibagikan dan sebaliknya mendapatkan respon dari konsumennya (Miles, 2014). Dalam konteks restoran, instagram menjadi semakin popular dengan adanya tren seni memotret makanan. Foto makanan dapat menjadi strategi promosi yang bertujuan untuk meningkatkan selera individu (Nisak \& Hariyanto, 2017). Ini merupakan momen yang digunakan restoran dan kafe untuk mempromosikan produknya melalui instagram.

Di sisi lain, penelitian terdahulu tentang media sosial banyak berfokus pada konten di twitter dan facebook (Bowen \& Baloglu, 2015; Virtanen, Björk, \& Sjöström, 2017) sehingga tidak banyak penelitian yang mengulas spesifik tentang Instagram dan penggunaanya di restoran Indonesia. Selain itu, mayoritas penelitian di Indonesia mengukur tentang pengaruh media sosial café/ restaurant terhadap minat beli dan keputusan pembelian (Arief \& Millianyani, 2015; Indika \& Jovita, 2017; Diyatma, 2017), dan tidak banyak penelitian yang memotret secara detail komponen komunikasi pemasaran restoran. Oleh karena itu, penelitian ini ingin menggambarkan bagaimana persepsi Follower instagram terhadap elemen-elemen komunikasi pemasaran yang dilakukan oleh restoran di Surabaya khususnya restoran yang memiliki banyak Follower (diatas 10.000). Hasil penelitian ini diharapkan dapat berkontribusi untuk pengembangan strategi pemasaran restoran dengan mengetahui komponen-komponen komunikasi pemasaran mana yang sudah berhasil dilakukan dengan baik dan yang mana yang masih butuh perbaikan. Selain itu, manfaat akademis yang diberikan dari penelitian ini adalah dapat menjadi referensi atau masukan bagi perkembangan ilmu pemasaran melalui sosial media dan menambah kajian tentang strategi pemasaran di sosial media instagram di Indonesia khususnya dalam bidang restoran dan café.

\section{Persepsi}

Persepsi adalah bagaimana orang-orang melihat atau menginterpretasikan peristiwa, objek, serta manusia (Lubis, 2010). Jadi, persepsi adalah keadaan dimana seorang individu dapat menginterpretasikan sesuatu berdasarkan ransangan yang diterima oleh stimulus. Hal ini dikemukakan juga oleh Sugihartono et al. (2007, p.8) dimana persepsi merupakan kemampuan otak dalam menerjemahkan stimulus atau proses untuk menerjemahkan stimulus yang masuk ke dalam alat indera manusia. Persepsi manusia memberikan perbedaan sudut pandangan dalam penginderaan. Ada yang mempersepsikan sesuatu itu baik atau 
positif maupun persepsi yang negatif yang nantinya akan mempengaruhi tindakan manusia.

\section{Komunikasi Pemasaran}

Komunikasi pemasaran dapat diartikan sebagai kegiatan komunikasi perusahaan untuk menginformasikan, mempengaruhi, dan mengingatkan konsumen mengenai produk yang dijual (Kennedy \& Soemanegara, 2006, p.3. Kotler \& Keller, 2009, p.510). Perencana komunikasi pemasaran, yakni perusahaan/bisnis, menggunakan berbagai cara agar konsumen selaku penerima pesan komunikasi dapat menangkap dan menerima pesan tersebut dengan baik. Oleh karena itu, sangat penting untuk membuat sebuah komunikasi pemasaran menjadi sebuah komunikasi yang efektif agar pesan pemasaran yang direncanakan dapat sampai dengan baik ke konsumen. Dengan demikian, pemasar perlu memahami bahwa proses penyampaian pesan dari pengirim pesan kepada penerima pesan melalui sebuah proses (Belch \& Belch, 2009, p.146). Proses komunikasi ini dijelaskan oleh Kotler \& Keller (2009, p.514) melalui gambar 1 berikut ini.

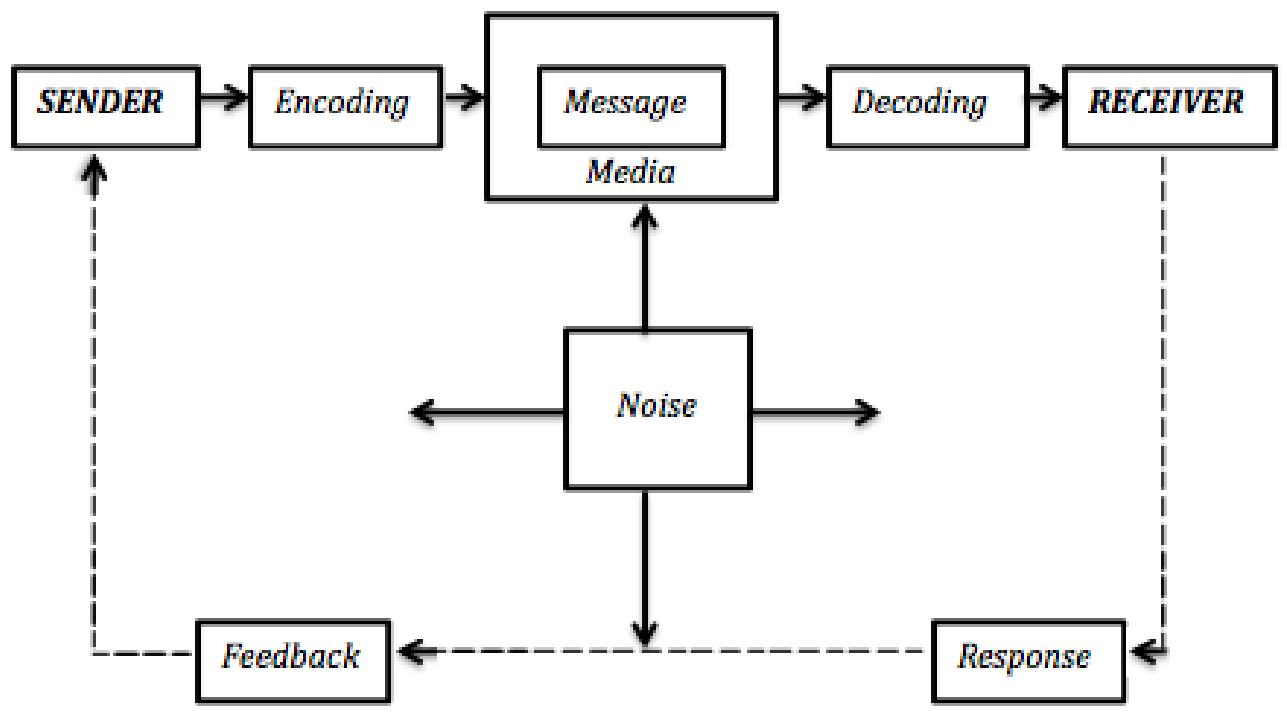

Sumber: Kotler \& Keller (2009, p.514)

Gambar 1. Proses Komunikasi

Proses komunikasi tersebut terdiri dari sumber informasi atau sender, yang mengubah pesan dengan encoding dan mengirimkannya melalui media tertentu. Pesan tersebut ditanggap dan diterjemahkan atau decoding oleh penerima pesan atau receiver. Proses penyampaian komunikasi ini membutuhkan komponen yang disebut bauran komunikasi pemasaran yang dijabarkan dalam 8 jenis, yaitu: Periklanan, Promosi Penjualan, Event dan Pengalaman, Hubungan Masyarakat dan Publisitas, Pemasaran Langsung, Pemasaran Interaktif, Pemasaran Word-of- 
Mouth, dan Penjualan Pribadi. (Kotler \& Keller, 2009, p.512). Karakteristik pesan dalam pemasaran interaktif adalah dapat diatur sedemikian rupa untuk menarik individu yang disasar, dapat dipersiapkan secara cepat dan terbaru, serta dapat diubah atau dimodifikasi sesuai respon yang diterima. (Kotler \& Keller, 2009, p.529).

\section{Komunikasi Pemasaran di Media Sosial}

Pemasaran dalam sosial media dapat dikategorikan ke dalam pemasaran interaktif, karena media sosial dapat diartikan sebagai sebuah media yang disediakan untuk penggunanya dapat berinteraksi, berkomunikasi, dan berbagi ide dan informasi melalui teknologi yang berbasis web atau mobile, seperti blogs, Facebook, YouTube, Twitter, Instagram (Virtanen, Bjork, \& Sjostrom, 2017 ; Ghiselli \& Ma, 2015). Ada 4 komponen pembentuk komunikasi pemasaran di sosial media, yaitu Konteks, Komunikasi, Kolaborasi, dan Koneksi (Solis, 2010). Komponen pertama adalah konteks, yang berbicara tentang bagaimana membentuk sebuah pesan yang baik bagi khalayak untuk menarik perhatian, memberikan informasi, dan pesan promosi. (Pusparini, 2015). Pembentukan konten yang ideal ini dapat berfokus pada grafik, warna, dan perancangan fitur yang menarik (Fauziah \& Trenggana, 2016). Selain itu, konten yang baik dapat dilihat dari kejelasan dan kelengkapan informasi yang sesuai dengan pesan yang ingin disampaikan (Putra, 2015). Oleh karena itu, bahasa yang digunakan harus jelas dan mudah dipahami (Indika, \& Jovita, 2017). Sebuah konten yang baik akan menampilkan pesan yang menarik perhatian dan juga bermanfaat bagi pengguna (McFarland \& Ployhart, 2015).

Komponen kedua adalah komunikasi, dimana dapat diartikan sebagai cara/tindakan untuk menyampaikan, membagikan, mendengarkan, merespon, dan mengembangkan pesan (Fauziah \& Trenggana, 2016). Salah satu keunggulan yang ditawarkan oleh media sosial dibandingkan dengan media konvensional lainnya adalah perusahaan dapat lebih mudah melakukan komunikasi dua arah yang harus dimanfaatkan dengan baik (McFarland \& Ployhart, 2015). Lee dan Benbasat (2004) mengatakan bahwa kategori komunikasi yang baik apabila dapat ditanggapi dengan cepat dan jelas. Perusahaan akan sukses apabila dapat memberikan jawaban yang sesuai dengan pertanyaan dari penerima pesan (Fauziah \& Trenggana, 2016). Komponen ketiga adalah kolaborasi, yang berupa kerjasama antara pemberi dan penerima pesan agar pesan yang disampaikan lebih efektif dan efisien (Fauziah \& Trenggana, 2016; Putra 2015). Dalam sosial media, bentuk kerjasama ini dilihat dari timbal balik positif dan tanggapan dari pengguna media sosial, seperti terus mengunjungi dan mencari informasi melalui media sosial perusahaan (McFarland \& Ployhart, 2015).

Komponen keempat adalah koneksi, yang menunjukkan hubungan yang berkelanjutan antara pemberi dan penerima pesan (Fauziah \& Trenggana, 2016). 
Perusahaan harus menjaga hubungan dengan melakukan tindaklanjut atau memperbaharui informasi dengan konsisten sehingga pengguna merasa hubungan yang terjalin sangat kuat dan tidak terputus. (Lee \& Benbasat, 2004). Penelitian sebelumnya membuktikan bahwa apabila empat kompenen komunikasi pemasaran restoran dapat diimplementasikan dengan baik, maka bukan hanya dapat meningkatkan minat beli (Arief \& Millianyani, 2015; Indika \& Jovita, 2017), tetapi juga akan berpengaruh pada keputusan pembelian konsumen (Diyatma, 2017).

\section{METODE PENELITIAN}

Restoran yang dipilih sebagai sampel penelitian ini adalah Madame Chang dan De Mandailing Surabaya yang memiliki jumlah Follower diatas 10.000. Selanjutnya, kriteria sampelnya adalah Follower yang aktif dan akun yang tidak dalam mode private yang artinya bisa diakses, dimana survei dilakukan dengan cara mengirimkan pesan atau (direct message) melalui Instagram. Kuesioner yang disebarkan terbagi menjadi 2 bagian, yakni bagian pertama berisi tentang profil dari responden, dan bagian kedua adalah pernyataan terkait persepsinya terhadap masing-masing komponen komunikasi pemasaran. Adapun skala yang digunakan yaitu 5-point Likert-type scale, dengan kategori satu (sangat tidak setuju) sampai lima (sangat setuju). Dari jumlah 4000 lebih kuesioner yang disebarkan, jumlah respon yang didapat adalah sebesar 791 kuesioner yang kembali dan valid, maka tingkat responnya sebesar $19.3 \%$.

Kuesioner yang diterima kemudian dianalisa dengan menggunakan analisa deskriptif mean dan standar deviasi. Hal ini untuk mendapatkan gambaran bagaimana persepsi Follower terhadap pemasaran restoran di instagram. Untuk menggambarkan persepsi Follower restoran di instagram, maka hasil nilai ratarata akan dibagi kedalam 7 kategori, sebagai berikut

Tabel 1. Interval Kelas

\begin{tabular}{cc}
\hline Nilai rata-rata & Kategori \\
\hline $\mathbf{1 . 0 0}-\mathbf{1 . 5 7}$ & Sangat Tidak Baik Sekali \\
\hline $\mathbf{1 . 5 8}-\mathbf{2 . 1 4}$ & Sangat Tidak Baik \\
\hline $\mathbf{2 . 1 5}-\mathbf{2 . 7 1}$ & Tidak Baik \\
\hline $\mathbf{3 . 2 9}-\mathbf{3 . 2 8}$ & Sedang \\
\hline $\mathbf{3 . 8 6}-\mathbf{4 . 4 2}$ & Baik \\
\hline $\mathbf{4 . 4 3}-\mathbf{5 . 0 0}$ & Sangat Baik \\
\hline
\end{tabular}

Sumber: diolah penulis.

\section{Definisi Operasional}

Konteks (KNT) mengacu pada bagaimana restoran membentuk pesan yang baik di akun Instagramnya. Indikatornya meliputi:

KNT 1. Isi gambar foto dalam instagram menarik perhatian.

KNT 2. Restoran menggunakan bahasa yang jelas dan mudah dipahami. 
KNT 3. Restoran memberikan informasi yang sesuai dengan kebutuhan anda.

Komunikasi (KMK) berarti bagaimana restoran menyampaikan, membagikan, mendengarkan, dan merespon pesan kepada Followers. Indikatornya terdiri dari:

KMK 1. Restoran menanggapi setiap pertanyaan yang diberikan dengan cepat.

KMK 2. Restoran menjawab pertanyaan dengan tepat (sesuai dengan apa yang ditanyakan).

KMK 3. Tanggapan restoran pada setiap pertanyaan jelas dan mudah dipahami.

KMK 4. Restoran menanggapi pertanyaan dengan bahasa yang terkesan ramah.

Kolaborasi (KLB) merupakan hubungan restoran dengan Followers. Indikatornya dibagi menjadi:

KLB 1. Follower selalu memberikan respon yang positif pada posting (like dan memberikan komentar yang positif)

KLB 2. Follower sering mengunjungi akun Instagram restoran (minimal sekali dalam satu hari)

Koneksi (KNK) mengacu pada hubungan yang berkelanjutan antara restoran dengan Follower. Indikator dari Koneksi meliputi:

KNK 1. Restoran selalu memberikan informasi dan promosi baru dengan konsisten

KNK 2. Restoran selalu menanggapi komentar dari Follower

Selain survei, metode observasi juga dilakukan untuk menjustifikasi hasil penelitian. Observasi dilakukan pada akun instagram restoran yang menjadi objek penelitian, dengan mengacu pada indikator pertanyaan survei.

\section{HASIL DAN PEMBAHASAN}

Berikut adalah gambaran tentang profil responden beserta perilakunya dalam menggunakan Instagram. Responden mayoritas adalah perempuan, berusia 17-24 tahun dengan pekerjaan sebagai pelajar/mahasiwa. Selain itu, mayoritas responden menghabiskan waktu 3-4 jam per hari untuk membuka Instagram. Kebanyakan dari responden juga mengetahui akun restoran melalui fitur "explore" dan rekomendasi teman/ kerabat. 
Tabel 2. Profil Responden

\begin{tabular}{|c|c|c|}
\hline & Jumlah & Prosentase \\
\hline \multicolumn{3}{|l|}{ Jenis Kelamin } \\
\hline Laki - Laki & 269 & 34 \\
\hline Perempuan & 522 & 66 \\
\hline \multicolumn{3}{|l|}{ Usia } \\
\hline $17-24$ tahun & 382 & 47.3 \\
\hline 25 - 34 tahun & 243 & 30.7 \\
\hline $35-44$ tahun & 122 & 15.4 \\
\hline $45-54$ tahun & 34 & 4.3 \\
\hline 55 tahun ke atas & 10 & 1.3 \\
\hline \multicolumn{3}{|l|}{ Pekerjaan } \\
\hline Ibu Rumah Tangga & 95 & 12 \\
\hline Karyawan Swasta & 189 & 23.9 \\
\hline Pegawai Negeri & 15 & 1.9 \\
\hline Pelajar / Mahasiswa & 305 & 38.5 \\
\hline Pengangguran & 1 & 0.1 \\
\hline Profesional & 31 & 3.9 \\
\hline Wirausaha & 154 & 19.5 \\
\hline \multicolumn{3}{|c|}{ Lama waktu yang digunakan membuka Instagram setiap hari } \\
\hline $1-2$ jam & 136 & 17.2 \\
\hline $3-4$ jam & 265 & 33.5 \\
\hline $5-6$ jam & 52 & 6.6 \\
\hline Kurang dari 1 jam & 145 & 18.3 \\
\hline Lebih dari 4 jam & 164 & 20.7 \\
\hline Lebih dari 6 jam & 29 & 3.7 \\
\hline \multicolumn{3}{|l|}{ Pendapatan / uang saku per bulan } \\
\hline Dibawah Rp. 3.000.000 & 278 & 35.1 \\
\hline Rp. 3.000.000 - Rp. 5.999 .999 & 263 & 33.2 \\
\hline Rp. 6.000.000 - Rp. 8.999 .999 & 145 & 18.3 \\
\hline Rp. 9.000.000 - Rp. 11.999 .999 & 49 & 6.2 \\
\hline Rp. 12.000 .000 ke atas & 56 & 7.1 \\
\hline \multicolumn{3}{|c|}{ Darimana mengetahui akun Instagram restoran } \\
\hline Food bloggers/influencer & 15 & 1.90 \\
\hline Gambar/foto di explore Instagram & 401 & 50.70 \\
\hline Rekomendasi teman/kerabat & 327 & 41.34 \\
\hline Informasi di dalam restoran & 26 & 3.29 \\
\hline Lainnya & 22 & 2.78 \\
\hline
\end{tabular}

Sumber: diolah penulis.

Berdasarkan tabel 1, maka berikut adalah pemaparan hasil nilai rata-rata persepsi Follower instagram restoran di Surabaya. Tabel 3 menunjukkan bahwa restoran Surabaya sudah sangat jelas dalam menggunakan bahasa untuk komunikasi pemasarannya di Instagram. Hal ini didukung oleh hasil observasi bahwa bahasa yang digunakan mayoritas adalah bahasa Indonesia yang lebih mudah dipahami oleh Follower yang kebanyakan orang indonesia. Selain itu, gambar/foto yang ditampilkan juga sangat menarik dengan skor 3.99.

Berdasarkan observasi, skor yang tinggi diindikasikan dengan gambar/foto yang diambil terkesan professional karena jelas, terang dan memiliki dominasi warna tertentu sesuai dengan warna identitas perusahaannya, serta mengugah selera. Temuan ini sejalan dengan yang disampaikan oleh Kuenn \& Kuenn (2015) 
dimana karakteristik foto yang mendapatkan banyak likes di Instagram adalah yang memiliki tingkat pencahayaan yang tinggi, dan satu warna yang mendominasi. Ekawati menambahkan (dalam Nisak \& Hariyanto, 2017) hal-hal yang perlu diperhatian untuk menghasilkan foto makanan yang baik adalah sudut pandang kamera, penataan sekeliling dan bahan-bahan yang digunakan harus terlihat segar dan bersih. Selanjutnya, menambahkan porsi dan hiasan makanan, menjaga tetap terlihat nyata, memilih tema yang tepat, serta menggunakan aksesoris yang sesuai serta alas atau latar yang bertekstur.

Tabel 3. Hasil Persepsi Follower

\begin{tabular}{|c|c|c|c|c|}
\hline No & Pernyataan & $\begin{array}{c}\text { Nilai } \\
\text { Rata-rata }\end{array}$ & $\begin{array}{c}\text { Std. } \\
\text { Deviation }\end{array}$ & Kategori \\
\hline KNT 1 & Gambar foto dalam instagram menarik & 3.99 & 0.757 & Sangat Baik \\
\hline KNT 2 & Bahasa yang jelas dan mudah dipahami & 4.00 & 0.743 & Sangat Baik \\
\hline \multirow[t]{2}{*}{ KNT 3} & $\begin{array}{l}\text { Restoran memberikan informasi yang sesuai } \\
\text { dengan kebutuhan }\end{array}$ & 3.79 & 0.827 & Baik \\
\hline & Konteks (KNT) & 3.93 & & Sangat Baik \\
\hline KMK 1 & $\begin{array}{l}\text { Restoran menanggapi setiap pertanyaan yang } \\
\text { diberikan dengan cepat }\end{array}$ & 3.67 & 0.804 & Baik \\
\hline KMK 2 & $\begin{array}{l}\text { Restoran menjawab pertanyaan dengan tepat } \\
\text { (sesuai dengan apa yang ditanyakan) }\end{array}$ & 3.80 & 0.784 & Baik \\
\hline KMK 3 & $\begin{array}{l}\text { Tanggapan restoran pada setiap pertanyaan } \\
\text { jelas dan mudah dipahami }\end{array}$ & 3.84 & 0.773 & Baik \\
\hline \multirow[t]{2}{*}{ KMK 4} & $\begin{array}{l}\text { Restoran menanggapi pertanyaan dengan bahasa } \\
\text { yang terkesan ramah }\end{array}$ & 3.99 & 0.752 & Sangat Baik \\
\hline & Komunikasi (KMK) & $\mathbf{3 . 8 3}$ & & Baik \\
\hline KLB 1 & $\begin{array}{l}\text { Follower selalu memberikan respon yang positif } \\
\text { pada posting (menekan tombol like pada pos } \\
\text { instagram dan comment yang positif) }\end{array}$ & 3.54 & 1.039 & Baik \\
\hline \multirow[t]{2}{*}{ KLB 2} & $\begin{array}{l}\text { Follower sering mengunjungi akun restoran } \\
\text { (minimal sekali dalam satu hari) }\end{array}$ & 3.02 & 1.250 & Sedang \\
\hline & Kolaborasi (KLB) & 3.28 & & Sedang \\
\hline KNK 1 & $\begin{array}{l}\text { Restoran selalu memberikan informasi dan } \\
\text { promosi baru dengan konsisten }\end{array}$ & 3.82 & 0.804 & Baik \\
\hline KNK 2 & $\begin{array}{l}\text { Restoran selalu menanggapi komentar dari } \\
\text { Followers }\end{array}$ & 3.68 & 0.839 & Baik \\
\hline & Koneksi (KNK) & 3.75 & & Baik \\
\hline & Komunikasi Pemasaran Secara Keseluruhan & 3.70 & & Baik \\
\hline
\end{tabular}

Sumber: diolah penulis.

Dari keseluruhan indikator dalam komponen konten, persepsi terhadap infomasi yang bermanfaat, mendapatkan nilai paling rendah 3.79, walaupun masih tergolong baik. Hal ini dapat disebabkan oleh restoran hanya berfokus pada membagikan foto produknya saja dan salah satu dari restoran yang diteliti membagikan produk yang sama dengan berulang kali dengan ajakan untuk mencoba makanan/minuman tersebut. Menurut Lasmadiarta (2011), penyampaian pesan berupa Informasi yang bermanfaat dapat membangun kepercayaan pembaca (dalam Muttaqin, 2011). Oleh karena itu, restoran harus fokus untuk membagikan 
konten yang sesuai dengan keinginan utama Follower sehingga dapat lebih bermanfaat dan sesuai dengan apa yang dicari konsumen. Selain itu, restoran perlu menciptakan pengalaman yang menyenangkan melalui akunnya misalnya dengan mengadakan kompetisi fotografi untuk suatu topik bahasan tertentu (Casaló, Flavián, Ibáñez-Sánchez, 2017). Secara keseluruhan, komponen konten pemasaran restoran yang memiliki lebih dari 10.000 Follower dinilai sudah sangat baik.

Responden memiliki persepsi bahwa keramahan dalam menjawab pertanyaan sudah sangat baik dengan skor tertinggi 3.99 dalam komponen komunikasi. Selebihnya, restoran juga dinilai baik dalam hal kejelasan dan ketepatan dalam menanggapi pertanyaan Follower. Akan tetapi, dari semua indikator dalam komponen komunikasi, restoran mendapatkan nilai yang paling rendah 3.64 pada kecepatan dalam menjawab pertanyaan. Berdasarkan observasi, hal ini kemungkinan disebabkan oleh beberapa pertanyaan yang dibiarkan tidak terjawab untuk waktu yang lama (lebih dari satu hari sampai satu minggu). Secara keseluruhan komponen komunikasi restoran dinilai baik oleh Follower.

Dari empat komponen komunikasi pemasaran restoran, komponen kolaborasi adalah komponen yang mendapatkan nilai paling rendah 3.28 dan termasuk pada kategori sedang. Nilai standar deviasinya juga paling tinggi dibandingkan dengan yang lain, hal ini menunjukkan bahwa jawaban responden yang beragam. Artinya, ada Follower yang sering mengunjungi dan merespon positif postingan dari akun restoran, tetapi ada juga yang pasif (tidak merespon dan jarang berkunjung ke akun restoran). Respon yang diberikan oleh Follower sangat berguna untuk membantu mempromosikan restoran, karena disaat sebuah post mendapatkan respon dari Follower, maka pengguna lain yang terhubung dengan Follower tersebut dapat melihat responnya di fitur explore (Online Business Buddy, 2013). Ini terbukti pada table 2, dimana mayoritas Follower yang menjadi responden penelitian ini mendapat informasi tentang akun Instagram restoran dari fitur explore. Untuk meningkatkan respon konsumen, maka penelitian dari Susanto (2016) membuktikan bahwa tema pesan yang memberikan banyak respon, baik dari likes terbanyak dan comments dari sebuah post adalah tema glitz and glam. Tema Glitz and Glam adalah tema pesan yang mengangkat tentang kemewahan dan sesuatu yang mempesona dan dapat disandingkan dengan hal-hal yang menunjukkan eksklusivitas yang dibungkus oleh produk-produk tertentu, contohnya ditampilkan melalui produk atau brand ternama, produk yang ekslusif, produk yang limited atau susah dijangkau, orang terkenal atau seorang tokoh tertentu dan keikutsertaan perusahaan sebagai pembicara atau peserta pada acara tertentu yang luar biasa. Susanto (2016) juga menyebutkan bahwa likes terbanyak pada instagram kafe adalah total 200 lebih likes. Temuan ini sejalan dengan hasil observasi bahwa restoran yang mengundang artis atau orang terkenal dan membagikan fotonya di halaman akun, mendapatkan lebih dari 200 likes. Penelitian lain menunjukkan bahwa persepsi 
konsumen terhadap kesenangan dan kegunaan memiliki pengaruh positif terhadap kepuasan pada akun Instagram, yang pada akhirnya bisa memberikan pengaruh positif pada minat untuk follow dan merekomendasikan akun tersebut (Casaló, Flavián, Ibáñez-Sánchez, 2017). Oleh karena itu, restoran perlu menawarkan informasi yang menarik, interaktif, dan customized seperti permainan interaktif, video and gambar, pilihan selera, kontes/lomba yang dapat memberikan konten yang menyenangkan. Hal ini terlihat dari hasil observasi dimana restoran yang memanfaatkan momen film superhero untuk memberikan kejutan kepada konsumennya dan dibagikan berupa posting, mendapatkan lebih dari 200 likes. Coelho, Oliveira, Almeida (2016) menyimpulkan bahwa Instagram akan lebih efisien digunakan apabila mengandung unsur keuntungan hedonis melalui keterikatan emosional daripada keuntungan komersial melalui promosi langsung terhadap produk, jasa ataupun harga.

Kompenen koneksi secara keseluruhan mendapatkan nilai 3.75 yang termasuk dalam kategori baik. Restoran juga dinilai selalu memberikan informasi terbaru dengan konsisten, yang dapat dibuktikan dengan hasil observasi dimana restoran yang diteliti posting konten di akunnya minimal sehari sekali dan bahkan ada yang menampilkan posting lebih dari satu kali dalam sehari. Dari kedua indikator dari komponen koneksi, indicator restoran selalu menanggapi komentar Follower mendapatkan nilai yang paling rendah 3.68. Nilai ini pun tidak jauh berbeda dengan dengan pernyataan bahwa restoran menanggapi pertanyaan dengan cepat. Hal ini diindikasikan dari hasil observasi bahwa, tidak semua komentar ataupun pertanyaan Follower yang dibalas. Oleh karena itu, restoran perlu memberikan perhatian lebih kepada komentar dan pertanyaan Follower.

\section{KESIMPULAN}

Studi ini memberikan gambaran terhadap komunikasi pemasaran yang dilakukan restoran khususnya yang memiliki Follower diatas 10.000. Hasil penelitian menunjukkan bahwa komunikasi pemasaran di restoran dipersepsikan baik oleh Follower. Komponen mendapat nilai paling tinggi adalah konteks, yaitu dalam hal bahasa yang digunakan jelas dan mudah dipahami, hal ini berarti penggunaan bahasa Indonesia dalam sosial media Instagram menolong pembaca untuk lebih memahami isi pesan. Selain itu, gambar/foto yang ditampikan dinilai sudah sangat menarik. Di sisi lain, kolaborasi adalah komponen yang dianggap masih belum optimal, sehingga restoran perlu memperbaiki konten pada akunnya dengan lebih menarik dan interaktif sehingga menimbulkan kesan yang menyenangkan, dibanding dengan hanya menampilkan informasi produk dan harga. Selain itu, restoran harus memperhatikan komentar dan pertanyaan Follower untuk ditanggapi dan dijawab secepatnya sehingga dapat menimbulkan komunikasi dua arah yang berkesinambungan. 
Penelitian ini hanya terbatas pada sampel restoran dengan Follower yang banyak, sehingga penelitian selanjutnya dapat membandingkan persepsi konsumen terhadap komunikasi pemasarannya di Instagram antara restoran dengan jumlah Follower yang banyak dengan jumlah Follower yang lebih sedikit. Selain itu, studi eksplorasi dengan kualitatif juga dapat dilakukan untuk mengetahui preferensi Follower terhadap komunikasi pemasaran restoran.

\section{REFERENSI}

Arief, G. M., \& Millianyani, H. (2015). Pengaruh Sosial Media Marketing Melalui Instagram Terhadap Minat Beli Konsumen Sugar Tribe. $e$ Proceeding of Management, 2(3), 2581-2587.

Belch, G. E., \& Belch, M. A. (2004). Advertising and Promotion: An Integrated Marketing Communications Perspective 6th. New York: NY: McGraw-Hill.

Bowen, J., \& Baloglu, S. (2015). Common themes across social media research. Worldwide Hospitality and Tourism Themes, 7(3), 314-319.

Casalo, L. V., Flavián, C., \& Ibañez, S. (2017). Antecedents of consumer intention to follow and recommend an Instagram account. Online Information Review, 41(7), 1046-1063.

Coelho, R. L., Oliveira, D. S., \& Almeida, M. I. (2016). Does social media matter for post typology? Impact of post content on Facebook. Online Information Review, 40(4), 458-471.

Digital Social Mobile. (2015, January). Retrieved from http://wearesocial.sg/blog/2015/01/digital-social-mobile-2015/

Diyatma, A. J. (2017). Pengaruh Promosi Melalui Media Sosial Instagram Terhadap Keputusan Pembelian Produk Saka Bisto \& Bar. e-Proceeding of Management, 4(1), 175-179.

Fauziah, A., \& Trenggana, A. F. (2016). Pengaruh penggunaan social media terhadap tingkatan brand awareness HijUp.com di kota bandung. Retrieved January 2017, from https://openlibrary.telkomuniversity.ac.i/home/catalog/id/116385/slug/penga ruh-penggunaan-social-media-terhadap-tingkatan-brand-awareness.html.

Ghiselli, R., \& Ma, J. (2015). Restaurant social media usage in China: A study of industry practices and. Worldwide Hospitality and Tourism Themes, 7(3), 251-265. 
Indika, D. R., \& Jovita, C. (2017). Media Sosial Instagram Sebagai Sarana Promosi Untuk Meningkatkan Minat Beli Konsumen. Jurnal Bisnis Terapan, 1(1), 25-32.

Kaplan, A. M., \& Haenlein, M. (2010). Users of the world, unite! The challenges and opportunities of social media. Bussines Horizons, 53(1), 59-68.

Kennedy, J. E., \& Soemanagara, R. (2006). Marketing communication: Taktik dan Strategi. Jakarta: PT Bhuana Ilmu Populer.

Kotler, P., \& Keller, K. (2009). Marketing management (13th ed.). New Jersey: Pearson Education, Inc.

Kuenn, A., \& Kuenn, B. (2015). Content Marketing Works: 8 steps to transform your business. Arizona: VM Press.

Lee, Y. E., \& Benbasat, I. (2004). A framework for the study of customer interface design for mobile commerce. International Journal of Electronic Commerce, 8(3), 79-102.

Lim, S. H., \& Yazdanifard, R. (2014). How Instagram Can Be Used as a Tool in Social Network Marketing. Retrieved January 2017, from https://www.researchgate.net/publication/265377226

Arfan, I., \& Ishak, M. (2010). Akuntansi Keperilakuan. Edisi Dua. Salemba Empat: Jakarta.

McFarland, L. A., \& Ployhart, R. E. (2015). Social media: A contextual framework to guide research and practice. Journal of Applied psychology, 100(6), 1653-1677.

Miles, J. (2014). Instagram Power: Build your brand and reach more customers with the power of pictures. USA: McGraw-Hill Education.

Muttaqin, Z. (2011). Facebook Marketing Dalam Komunikasi Pemasaran Modern. Teknologi, 1(2), 103-109.

Nisak, K., \& Hariyanto, D. (2017). Food Photography dan Eating Out di Media Sosial Instagram. KANAL: Jurnal Ilmu Komunikasi, 6(1), 31-40.

Online Business Buddy. (2013). Instagram: Explode your business today! Haven Publishing Group. 
Pusparini, M. (2015). The influence of social media use (Facebook and Twitter) on brand equity of canon camera Indonesia. Retrieved January 2017, from http://www.academia.edu/3543874/the_influence_of_social_media_use_fac ebook_and_twitter_on_brand_equity_of_canon_camera_indonesia

Sugihartono, K. N. F., Harahap, F., Setiawati, F. A., \& Nurhayati, S. R. (2007). Psikologi Pendidikan. Yogyakarta: UNY.

Susanto, T. E. (2016). Pesan dan Respon Dalam Proses Komunikasi Pemasaran Kafe Melalui Instagram. Jurnal E-Komunikasi, 4(1), 2-12.

Virtanen, H., Bjork, P., \& Sjostrom, E. (2017). Follow for Follow: Marketing of a Start-up Company on Instagram. Journal of Small Business and Entreprise Development, 24(3), 468-484. 